\title{
A Legitimate End to Illegitimate Beginning: A Critical Analysis of Mariam's Character in A Thousand Splendid Suns
}

\author{
Samina Akhtar ${ }^{1}$, Muhammad Rauf ${ }^{2}$, Saima Ikram $^{3}$ \& Gulrukh Raees ${ }^{4}$ \\ ${ }^{1}$ Department of English, Government Girls Degree College Gulshan Rehman, Peshawar, Pakistan \\ ${ }^{2}$ Department of Social Sciences and Humanities, CECOS University, Peshawar, Pakistan \\ ${ }^{3}$ Department of English, Qurtuba Univeristy of Science and Information Technology, Peshawar, Pakistan \\ ${ }^{4}$ FAST-National University of Computer and Emerging Sciences, Peshawar, Pakistan \\ Correspondence: Samina Akhtar, Department of English, Government Girls Degree College Gulshan Rehman, \\ Peshawar, Pakistan. E-mail: meenaiftikhar@yahoo.com
}

\author{
Received: February 12, 2017 Accepted: February 27, $2017 \quad$ Online Published: February 28, 2017 \\ doi:10.5539/ells.v7n1p113 URL: http://doi.org/10.5539/ells.v7n1p113
}

\begin{abstract}
This paper is an attempt to portray the plight of Mariam that she undergoes due to her illegitimate social status. The study focuses on the critical societal attitude towards the illegitimate unfortunate women. Mariam begins her life with a "harami" status; continues her struggle for personal identity, suffer and endures as a battered woman and leave this world as a woman of consequences by digging herself out of the lower social status that society attached to her. The study analyzes Mariam's endurance, struggles and resistance in her strenuous journey to attain legitimate ending. The researcher used feminist literary criticism to interpret the text as a research methodology and adopted close textual analysis of the text by Khaled Hosseini, A Thousand Splendid Suns.
\end{abstract}

Keywords: A Thousand Splendid Suns, Mariam, illegitimate child, inner conflicts, resistance, legitimate end

\section{Introduction}

Khaled Hosseini's (Note 1) A Thousand Splendid Suns is an account of female oppression and marginalization. It ventures realistically the predicament of Afghan women in a patriarchal social setup with the subsequent sadistic conducts, discriminations and injustices. It pictures how men ascertain their masculine authority and hence accomplish their needs by physically and mentally exploiting women. On the other hand, it movingly portrays how women tolerate such inhumane treatment ratified upon them.

The novel unveils the dark face of a patriarchal country through the impediments faced by the "harami" (Note 2) (illegitimate) woman. In an Afghan patriarchal setup, men enjoy complete authority over women, whether it is their wife or a stranger on the street, a woman must comply with every order put to her. And if they do not obey their orders, they can go through beatings, murder, and humiliation. Mariam and Laila, the two female protagonists of the novel, suffer continuous victimization and oppression because they want to provide a better life for the children. Aziza and Zalmai give Mariam and Laila the power to continue in a set-up that is not in their favour.

Women in Afghanistan have been facing gender discrimination for generations. Its severity over the years has gone unnoticed for it has become a norm of their culture and society. Through the character of Mariam the writer raises the issue of feminism and gender inequality. This paper aims to explore the long journey of endurance and resistance against oppression and loss of identity of Mariam. Being an illegitimate daughter of a wealthy man, Jalil, Mariam suffers oppression and victimization throughout her life. She experiences conflicts, hurdles and challenges when she tries to fit into the society's tasks and search for her personal identity and recognition at the same time.

Mariam is an unwanted child of an affluent entrepreneur Jalil. She is presented as a subaltern, (Note 3) an inferior woman in social, political and economic hierarchies. She belongs to a lower social class of women and is deprived of the opportunities to get some control over her life through education, and so, she is damned to a submissive, substandard life without choices. Her mother tells her from the very beginning that: "There is only one skill a woman like you and me need in life, and they don't teach it in school... And it's this: tahamul. Endure" 
(p. 17). Being a member of the lower social class she learns to endure passively and agrees to succumb to the patriarchal values. After realizing her oppression and degradation she decides to resist the male dominated world to claim her lost identity. Once a dull woman stripped of her womanliness and social rights because of her status as a "harami" child, Mariam becomes a class-breaking revolutionary woman who surmounts "illegitimate beginnings" to get a "legitimate end" (p. 329).

\section{Illegitimate Beginning}

Mariam's misfortune starts the day she is conceived by Nana. Mariam is described as an outcast and the reason of her mother's displeasure, disappointment, discontent and shame. The novel begins with an annoyance word, bitterly spoken in frustration by Nana, when Mariam shatters a precious heirloom. Nana seizes her by her hand, drags her close and angrily says: "This is my reward for everything I've endured. An heirloom-breaking, clumsy little harami" (p. 4).

Being an innocent kid, Mariam does not understand what this word harami-bastard means. She only takes it as her mother bitterness and dislike for her. Being a child she cannot defy the chauvinism, she is not able to see that it is the inventor of the harami who is responsible for the crime and not the harami, whose only fault is being born. Mariam becomes the victim of such harsh treatment since her childhood and it extends throughout her lifetime till she decides to resist against her violation. Later on Mariam comprehends that,

.... harami was an unwanted thing; that she, Mariam, was an illegitimate person who would never have legitimate claim to the things other people had, things such as love, family, home, acceptance (p. 4).

Mariam, an illegitimate daughter of a lower class mother, is always banished from her desired freedom. For her, freedom is to go to school, to learn and to play. Her journey of hope ends when her embittered mother tries to squash: "What's the sense schooling girl like you? It's like shining the spittoon. And you'll learn nothing of value in those schools" (p. 17).

Jalil is the representative of the affluent men who cares about his status and outer show rather than his children. He leads his life without having any concern for his daughter. It is because of society's pessimistic attitude towards the illegitimate children that Jalil acts in this way. Hosseini's portrayal of these facts serves to show that in Afghan culture marriage is not associated with true love, but rather with feasibility. Marriage is only the compulsion and convention in patriarchy. He compelled Mariam to marry Rasheed, a man who is three times of her age. Her approval is just a formality.

\section{Mariam's Journey as a Battered Wife}

Rasheed belittles Mariam in every possible way and repeatedly reminds her of how she should not be. He claims that he wishes to protect his wife, but he intends to dominate and control her. Mariam lives in terror of Rashid's varying moods and his impulsive disposition that often ends in contempt, ridicule, violence, and beating. His viciousness is obvious from his violent behavior towards Mariam when he compels her to chew solid pebbles as a retribution for not cooking according to his taste: "He shoved two fingers into her mouth and pried it open, then forced the cold, hard pebbles into it, urged her to chew it" (p. 104).

Through Mariam's adaptation to the hopes of her as a wife, Hosseini identifies the way society enlightens and directs behavior through gender. Rasheed earns only hatred from Mariam through such inhumane treatment and he does not recognize that when the tormenter excessively uses violence, the subjugated revolt against the dominant to defend the dear ones.

Mariam becomes an outcast again when she miscarries one child after another. The baby was a symbol of hope and a ray of light in her bleak living. But her inability to give birth to a child reduces her to the position of Rasheed's servant. He never tries to understand Mariam's agony for the child she lost. "Mariam grieved for this baby, this particular child, who had made her so happy for a while" (p. 93). She is grieved because with the death of the baby, she has lost her own hope of a happy life. Male dominance in Afghan Society is clearly exhibited in Rasheed's demeanor and ill-treatment of Mariam's abortions. His mood changes drastically. "With each disappointment (six other miscarriages), Rasheed had grown more remote and resentful. Now nothing she did pleased him" (p. 98).

The domestic friction turns to outright abuse and torture Mariam mentally and physically. Mariam silently bears the cruelties of her vicious husband because she lacks the courage to voice against the established norms set by the men. In a traditional Afghan society women's value has been judged by her fertility and her ability to bear male children. Azizah Al-Hibri, a Middle Eastern feminist theorist argues that having son means "immortality" because he is the source to carry on the family name and the role of women in the patriarchal society is that of an incubator (Note 4). 
Rasheed has central power over Mariam and Laila throughout their lives until they decide to resist his "patriarchal terrorism" (Note 5). They strictly must tolerate everything: his shifting moods, his discontent with their cooking, cleaning, abuse, insult and handling as if they are useless. He thinks of them as things not as human beings. Women are considered men's chattels. For instance, Rasheed, very insolently explained Laila that "A women's face is her husband's business only" (p. 48). This is a clear example of a male distressing a female that he is the possessor.

Mariam passively accepts her violation and succumbs to her sufferings instead of fighting it which fades the feminism in her. Mariam's tiring voyage from an illegitimate daughter to a desolate wife clearly depicts the miserable plight of women in a male chauvinist society. Being a "harami" society puts Mariam in the lowest social class and her barrenness penalized her role as a woman and puts her in the lowest class of women.

Mariam like her mother Nana appears to be an archetype who never in her life demands for her own sake rather sacrifices her desires for others. Because she has learnt from her mother that "endurance" is the only way of survival in the male oriented society. These lower class women are constantly tortured and deprived of fully realizing their capabilities. They lack the courage and strength to bluntly resist the standard norms of the society and are ragged between the conventional norms and their own emotions.

Mariam grows up believing that she is a futile "harami" and the society will never appreciate her. She, therefore, accepts and subdues herself to the life she is forced to live. She is convinced that it is her destiny and continues to endure the domination, oppression and victimization. She never objects or resists Rasheed's exploiting behavior. If he is distraught with her serving of food, she expresses regret for her fault. The cruel husband treated her like debris and she presents him all in return.

It wasn't easy tolerating him talking this way to her, to bear his scorn, his ridicule, his insults, his walking past her like she was nothing but a house cat. But after four years of marriage Mariam saw how much a woman could tolerate when she was afraid (p. 89).

Such a strained and disrespectful relationship makes Mariam live in threat and fear. Rasheed demoralizes and humiliates her by calling her bad names, abuses her, and even beats her physically. Mariam's life is an example of the situation of other women in Afghanistan who are leading life in constant fear of their husbands. Rasheed does not approve of anything that Mariam does. He always complains, "Now you know what you've given me in this marriage. Bad food, and nothing else" (p. 94)

\section{Mariam's Inner Conflict}

Mariam's inner conflict starts the day Rasheed decides to marry Laila and dishonor Mariam. He forbids her to show any kind of resistance in this matter. He reminds her in insulting manner that, "It's a common thing... your own father had three wives. Besides, what I am doing now most men I knew would have done long ago" (p. 192).

Mariam feels worthless once again and all her hopes of having a happy married life dashes to the ground. She regrets the sacrifices she made for the vicious and ungrateful husband. It is there when the readers understand her personal feelings concerning Rasheed and about her conjugal life. She starts questioning herself, "Had she been a deceitful wife? A complacent wife? A dishonorable woman" (p. 309)? She tries to find faults in herself. She wants to know the reason of her being so common and worthless. She wants to understand why she is so discreditable all her life. Mariam little femininity compels her to seek valid answer for her disgrace and the oppression she faces in her married life. She questions,

What harmful things had she done to this man to warrant his malice, his continual assaults, and the relish with which he tormented her? Had she not given this man her youth? Had she ever justly deserved his meanness? (p. 309).

The above passage suggests that women can tolerate every brutality but cannot compromise on self- respect and dignity. Humiliation and disgrace transforms a passive woman like Mariam into an active feminist. She decides to resist the degrading attitude of Rasheed at her own risk as Foucault states that "there always remain the possibilities of resistance, disobedience and opposition" (as cited in Foucault, p. 11).

It is the common horror of Rasheed's unreasonable brutality that brings the two women, Mariam and Laila closer. On several occasions, Laila comes to save her from Rasheed's aggression and this helps to develop a bond between the two women. Hans Toch states in Violent Men (1969), "Violence, ironically, creates harmony among otherwise warring elements" (p. 33). The viciousness faced by Mariam and Laila, the commonality of their sufferings and experiences persuade them to get together in a common cause, that of dealing with the vicious husband. Through her beliefs of class equality she overcomes the social differences with the lower class Mariam. 
And she encourages Mariam to resist against the continuous gender injustices they are facing. She knows they have the potential to struggle for their freedom and break the chains of the patriarchy. Laila is the representation of the women of Afghanistan who through their struggle against violence prove that they still have a spirit to challenge their discriminatory, biased and downtrodden image.

Mariam creates a strong bond of affection with Laila and her daughter and renovates herself into a prototype gallant mother and not even hesitates to kill her tyrant husband. She refuses to bear the burden of false indictments without any resistance. She realizes that mere subjugation and subservience without any protest, defense and resistance strengthen the tyrants to defeat humanity. It is this selfless love, satisfaction and delight which creates self confidence in Mariam and forces her to resist and defy openly against the oppression and victimization she is subjected to in the male chauvinist society. Through her spirited actions thereafter, Mariam proves that:

A woman is a being. She is not an appendage of man. A woman is not the other. She is not an addition to man. She is an autonomous being, capable of, through trial and error, finding her own way to salvation" (as cited in Ramamoorthy, p. 115).

\section{Legitimate Ending}

Mariam's decision to resist against the tyranny of her husband leads her towards the attainment of legitimate ending. Her daring step at the time when Rasheed hits and chokes Laila is inevitable. The commonality of their adverse experiences helps the development of a union to protect themselves against a common antagonist, their husband. In a male dominant Afghan society, coming together in a group is difficult for women but the understanding of at least these two women is representative of the determined and unyielding effort of women.

Rasheed becomes furious when he comes to know about Tariq's visits to Laila. He considers Mariam guilty and plans to hurt them both. He strikes both of them horribly and it is obvious from his intentions that he wants to take their life. Rasheed hits and chokes Laila, and in this critical time Mariam decides to resist:

And so Mariam raised the shovel high, raised it as high as she could, arching it so it touched the small of her back. She turned it so the sharp edge was vertical, and, as she did, it occurred to her that this was the first time that she was deciding the course of her own life (p. 311).

Mariam's eventual stroke against Rasheed that ends in his demise signifies that she has tolerated greatly. She needs to resist the cruel norms and Rasheed's viciousness. She wants to protect herself and others from the tyranny of a violent man. She takes an immense step and refuses to accept the power of society. Death emerges like the most credible decision to get away from the precarious assault of the Soviet Union, the tyrannical regime of the Taliban, or an offensive husband. Her whole life she tries to conform to Rasheed's ways, and suffers more than any woman should have to tolerate in a life. She does not allow the people to snatch anything from her and in the end she dies a hero.

By killing Rasheed, she takes herself out of the gender and class domination that she has faced throughout her life. Through her daring action she proves that the subjugated can rise up against the tormentor for protecting the dear ones by sacrificing her own life. Herbert Marcuse, in his essay entitled "Essay on Liberation" (1969) termed this inevitable killing act of Mariam as a certain degree of radical social change. He considers oppression, victimization and gender exploitation the main reasons for social upheavals which occur when one cannot tolerate domination and humiliation any longer. Marcuse says:

Freedom would become the environment of the organism which is no longer adaptable to the competitive performances required for well-being under domination, no longer capable of tolerating the aggressiveness, brutality, and ugliness of the established way of life (p. 236).

Mariam represents those women who endeavor hard to be conventional and abide by the roles that are specified by the society and their culture, but are unfortunately compelled to take the affairs into their own hands. For instance in Lady Oracle (Note 6) (1976), the female protagonist, Joan Foster, is initially introverted, cowardly and indecisive but finally she changes her mind. She rebels and resist against the male-dominated social order and gets an identity of a feminist author.

Mariam decides to stay and face the consequences of their murdering Rasheed. She surrenders her life for Laila and the children, and accepts her destiny. She is put to death by the Extremist. Since she commits an offense against patriarchy (Note 7) she must suffer a patriarchal ending. Socialist feminist Sheila Rowbotham says that once the governing state is busted the previously oppressed state must acknowledge the fundamental social change it has executed. In order to reveal the real identity, the socialist must let go of the tormenter's account of stress and "create their own way of seeing" (p. 281) Mariam's death suggests freedom of soul and body from the 
oppression and victimization that continue for years in the flimsy state of Afghanistan. In respect to the country, there cannot be liberation until the oppression ends, one escape or die. Mariam meditates:

She thought of her entry into this world, the harami child of a lowly villager, an unintended thing, a pitiable, regrettable accident... And yet she was leaving the world as a woman who had loved and been loved back. She was leaving it as a friend, a companion, a guardian. A mother. A person of consequence at last... This was a legitimate end to a life of illegitimate beginnings (p. 329).

Through feminist perspective, one can judge Mariam's murder of Rasheed as an act in which she digs herself out of the gender oppression that troubles her throughout her life. And after killing Rasheed, we see a transformed Mariam, resolute and full of confidence. She stays to face the consequences fearlessly. Once a dull woman stripped of her womanliness and social rights because of her status as a "harami" child, Mariam is now a class-breaking revolutionary woman who surmounts "illegitimate beginnings" to get a "legitimate end"(p. 329).

Mariam realizes in her concluding moment of life that the stain of "harami" that her mother has given her is not meant to persist with her; it has been removed. She enters into the world considering she signifies nothing, but she succeeds in changing the assumption and leave the world as something. Mariam sacrifices her precious life to bring peace, harmony and freedom in others' lives. "As she closes her eyes, it was not regret any longer but a sensation of abundant peace that washed over her" (p. 370). Mariam feels satisfied to turn into a "person of consequence," having cherished people in her life (p. 329).

The feeling of content overwhelms Mariam before she is put to death as she feels that her daring act brings change not only in Laila and Aziza's life but in her country Afghanistan. "She has chosen death so that Laila and the children, together with Tariq, can find a sanctuary where they will thrive in peace and security." (Cited in Stuhr, p. 62). She endures as she is believed to, and once she endured a lot she acts upon this. "One could not count the moons that shimmer on her roofs or the thousand splendid suns that hide behind her walls" (p. 172).

\section{Conclusion}

The conclusion of the study attempts to give a concise overview of the whole discussion and concludes that $A$ Thousand Splendid Suns is a façade of female resistance against oppression, victimization and loss of identity. It explores the story as a legitimate ending to an illegitimate beginning and Mariam's realization of self-identity and feminism. The study is an effort to unveil and emphasize some of the wickedness, and gender injustices that prevails in the patriarchal society in order to eradicate these social problems.

Mariam wields her strength to struggle against her tyrant husband Rasheed and resolve her own life by killing him to save Laila and Aziza: her only true love ideals. A Thousand Splendid Suns is a true representation of a patriarchal and imperialistic Afghan society, and describes the factors that have limited women's opportunities for a meaningful and evocative life. In the novel, it is women who suffer alone, have no chances for education, no fulfillment of desires, no freedom to speak, lack warmth and are obliged to suppress their basic needs. The novel truly reflects the philosophy of life and identification of Afghan women.

In A Thousand Splendid Suns, the dreadful influence of patriarchy is efficiently revealed through the presentation of Mariam's life. She becomes the victim of the viciousness of the political and social canon of the Afghan society and her only fault is that she is simply a woman. What is really tragic about Mariam is her illegitimate birth due to which she tolerates the unsympathetic society throughout her life. What Khaled Hosseini depicts in the novel is very critical not only for the women folk in Afghanistan but also for humanity at large. Women in Afghan society is really struggling and fighting for their survival and existence of being born women.

The study aims to motivate women into developing the resistance and strength which lies within them to fight for their happiness just like the strength that has been displayed by Mariam in the novel. The violence and oppression she endures is not something which has to be moaned only, but it is something to be confronted and fought back. Mariam's efforts and resistance against subjugation and discrimination determines active feminism on her part.

\section{References}

Al-Hibri, A. (1981). Capitalism Is An Advanced Stage of Patriarchy: But Marxism Is Not Feminism. In L. Sargent (Ed.), Women and Revolution (pp. 165-194). Boston: South End.

Angemeer, A. D. (2012). Reading the Other and Reading Ourselves. An Interpretive Study of Amazon.com Reviews on Bestsellers about Muslims. Proquest Llc (p. 241). Diss. University of Pittsburgh.

Atwood, M. (1976). Lady Oracle. New York: Anchor Book.

Ferguson, A. (1989). Socialist Feminism: New Consciousness, New Practice. An Anthology of Western Marxism. 
In R. Gottlieb (Ed.), From Lukacs and Gramsci to Socialist Feminism (pp. 348-372). New York: Oxford UP. Hooks, B. (2000) Feminism is for Everybody. Boston: South End Press.

Hosseini, K. (2007). A Thousand Splendid Suns. New York: Riverhead Hardcover.

Johnson, M. (1995). Patriarchal Terrorism and Common Couple Violence: Two Forms of Violence against Women. Journal of Marriage and Family, 57(2), 283-294. https://doi.org/10.2307/353683

Marciniak, J. (n. d.). Suns and Daughters: The Role of Marxism and Women in Khaled Hosseini's $A$ Thousand Splendid Suns. Retrieved from https://www.academia.edu/319104/_Suns_and_Daughters_The_Role_of_Marxism_and_Women_in_Khaled _Hosseini_s_A_Thousand_Splendid_Suns

Marcuse, H. (1989). An Essay on Liberation. An Anthology of Western Marxism. In R. Gottlieb (Ed.), From Lukacs and Gramsci to Socialist Feminism (pp. 234-237). New York: Oxford UP.

Mill, J. S. (2012). The Subjection of Women. London: Longmans, Green, Reader \& Dyer. (1869 first ed).

Moghadam, V. M. (1992). Patriarchy and the politics of gender in modernizing societies: Iran, Pakistan and Afghanistan. International Sociology, 7(1), 35-53. https://doi.org/10.1177/026858092007001002

Ramamoorthy, P. (1991). My life is my own-A Study of Shashi Deshpande's Women. In S. Singh (Ed.), Feminism and Recent Fiction in English. New Delhi: Prestige Books.

Rowbotham, S.(1973). Woman's Consciousness, Man's World. (A pelican original). Print.

Ruthven, K. K. (1984). Feminist Literary Studies: An Introduction. Mildly Edgeworn, Cambridge: Cambridge University Press.

Spivak, G. S. (2010). Inresponse: Looking back, looking forward. In R. C. Morris (Ed.), Can the Subaltern Speak? Reflections on the History of an Idea. New York: Columbia University Press.

Stuhr, R. (2011). A Thousand Splendid Suns: Sanctuary and Resistance (pp. 61-62). Penn Libraries.

Toch, H. (1969). Violent Men: An Inquiry Into the Psychology of Violence. Chicago: Aldine Publishing Co.

\section{Notes}

Note 1. Khaled Hosseini, a well-known Afghan-American novelist, was born in 1965 in Kabul, Afghanistan. In 1980, his family asks for and is allowed political asylum in the United States as by then Afghanistan has already suffered a ruthless communist takeover and the incursion of the Soviet army followed by the American Invasion and the dreadful reign of the Extremists. Hosseini graduated in 1984 and has received a Bachelor's degree in biology in 1988. He got a Medical Degree in 1993, from Diego's School of Medicine; University of California. Hosseini is a committed internist between 1996 and 2004. His literary career started with the publication of his first novel, The Kite Runner (2003), that is admired for its ethnographic and historical importance, his next novel, A Thousand Splendid Suns, published in 2007, depicts the relationship between two Afghan Women with the same misogynistic husband. He has recently published his third novel And the Mountains Echoed, in 2013. He has won numerous awards for his novels. All his novels deal with relationships, family bonding, violence, gender equity, homeland and nationality. The Extremists control over Afghanistan is another theme common in his novels. His work also exposes the affliction Afghanistan has passed through in a quarter century of divergence and conflicts. Also, many characters in his novels convey their fondness and connection to their native country, Afghanistan.

He was named a goodwill envoy to UNHCR, the United Nations Refugee Agency in 2006. Hosseini is genuinely anxious about his native country. He has been working to provide compassionate help in Afghanistan through "The Khaled Hosseini Foundation" which provide sanctuary to refugee families and economic and education opportunities and healthcare for children and women from his native country. (Angemeer, pp. 92-93). For further details see Angemeer, Alicia Dorothea. Reading the Other and Reading Ourselves: An Interpretive Study of Amazon.com Reviews on Bestsellers about Muslims. (Diss. University of Pittsburgh, 2012).

Note 2. Mariam comes to this world as a "harami", an illegitimate child of a wealthy businessman Jalil. She suffers humiliation and oppression throughout her life due to her illegitimate beginning. Hosseini states in his novel, "a harami was an unwanted thing; that she, Mariam, was an illegitimate person who would never have legitimate claim to the things other people had, things such as love, family, home, and acceptance" (4). 
This unwanted status snatches freedom from Mariam. She is not considered worthy of anything as the other people of the society. It is not only physical ability which is reduced by her illegitimate birth, but her privileges to have family, love and recognition. Mariam is very active both physically and psychologically, but she is marginalized because of her harami status all her life by her father, husband and the society as a whole. She is insulted, dispelled and beaten as a worthless object. After years of humiliation she recognizes her self-respect and tries to resist the inhumane treatment in the hands of the dominating men who over powered her. She collects enough courage to kill her tyrant husband Rasheed at the price of her own peril. Her scarifies gives a new life to Laila and her children. She feels contented to have become a "person of consequence," having loved people in her life (p. 329). Mariam digs herself out of the harami status attached to her by the society and becomes a class-breaking revolutionary woman who overcomes "illegitimate beginnings" to get a "legitimate end" (p. 329)

Note 3. The term "subalternity" is employed by a prominent feminist Spivake, used for all those who are marginalized and deprived of the "voice" to "speak". For details see "Subalternity: A Question in Amitav Gosh and Khaled Hosseini", Shouket Ahmad Tilwani.

Note 4. For detail see, Marciniak Jennifer's "Suns and Daughters: The Role of Marxism and Women in Khaled Hosseini's A Thousand Splendid Suns,"

Note 5. The term patriarchal terrorism, envisioned by Johnson (1995), is the fanatic control of wives by patriarchal spouse that keep the methodical use of not only violence and aggression but also monetary subordination, terrorization, segregation, and other dominating strategies. Due to the patriarchal social structure of the culture, the protagonists of the narrative fall victim to such type of terrorism. In their daily lives, Mariam and Laila suffer different kinds of oppression and violence such as rebuke, contempt, risks, and mental and physical violence. In one instance, Rasheed despises Mariam and call her an illicit village girl whose worth is to be "a good worker without pretensions" (Hosseini, p. 222). He repeatedly flings the food at Mariam when it has not been ready according to his taste. One night, he forces her to put a handful of pebbles into her mouth as a retribution for not cooking to his flavor: "He shoved two fingers into her mouth and pried it open, then forced the cold, hard pebbles into it, urged her to chew it" (Hosseini, p. 104). $\mathrm{He}$ also treats his other wife, Laila in the same humiliating manner. Johnson termed all such violence as patriarchal terrorism.

Note 6. Lady Oracle is Margaret Atwood's third novel, published in 1976. It is a five-part narrative. Joan Foster is the protagonist and first-person narrator who tells the story of her life.

Note 7. Feminist theory considers patriarchy as an unfair system of the society that implements gender roles and is cruel to male and female. Patriarchy has always become the main concern of women's struggle for equal rights. In patriarchal culture women are always given an inferior position which forces them to be discriminate and marginalized from their rights.

\section{Copyrights}

Copyright for this article is retained by the author(s), with first publication rights granted to the journal.

This is an open-access article distributed under the terms and conditions of the Creative Commons Attribution license (http://creativecommons.org/licenses/by/4.0/). 